\title{
Academic and Social Expectations of Incoming College Students
}

\author{
Ryan Korstange, Assistant Professor of University Studies and \\ Coordinator of UNIV 1010, Middle Tennessee State University
}

\section{Thomas M. Brinthaupt, Professor of Psychology and Director of Faculty Development, Middle Tennessee State University}

\author{
Autumn Martin, Undergraduate Psychology Student, Middle \\ Tennessee State University
}

Students' beliefs about themselves and their abilities shape their firstsemester college experience. This article examines the mindset of incoming college students, with particular focus on their beliefs about their intelligence, need for cognition, and goal orientation in both the academic and social domains. In order to examine some of the ways in which students operationalize their beliefs, we also asked students $(\mathrm{N}=$ $332)$ to rate their likely reactions to a variety of hypothetical academic and social situations they might encounter during their first year of college. Our goal was to expand the conversation about the "college-ready" student mindset and develop a more accurate picture of the various beliefs that students have when they enter college. In both the academic and social domains, participants rated the mindset items toward a growth perspective, the cognition items toward higher enjoyment of thinking, and the goal orientation items toward a preference for minimizing trouble and mistakes. The results also indicated significant ethnicity, gender, and ACT score differences across the major measures, but not first-generational status differences. These results suggest that student support programming should take into consideration variations in student mindset. 
Keywords: First-year experience, student success, college-ready mindset, academic experiences, social experiences

Author Note: Financial support for this research was provided by a NODA Catalyst Grant. We wish to thank Matthew D. Duncan and Cheryl Torsney for their comments and feedback on an earlier version of this paper.

Corresponding author: Ryan Korstange, Middle Tennessee State University

Statistics related to first-year student success are sobering. A full $20 \%$ of first-year students enrolled in four-year colleges do not persist until their sophomore year and the national six-year graduation rate is a meagre $60 \%$ (National Center for Education Statistics, 2018). More alarmingly, lowincome, first-generation, and underrepresented minority students persist and graduate at even lower levels (National Center for Education Statistics, 2018). There is an implicit connection between first-year retention rates and six-year graduation. Castleman and Meyer (2018) suggest that a "student's freshman year of college is pivotal for determining the trajectory of their postsecondary success" (p. 249). In other words, the majority of college dropouts happen after, or even because of, the first year.

Many studies of student success programming and statistics are retrospective. Their point of departure is those students who have proven to be successful by various measures (GPA, involvement, persistence, graduation, etc.) and the studies work backwards to determine the common factors or dispositions among students who turned out to be successful. This methodology makes sense, but it leaves out valuable information regarding the expectations and capabilities of incoming students, and importantly disregards the effect that a student's expectations play on how they understand key points of transition through their college career.

This study reverses the retrospective trend and identifies critical student beliefs about college before classes begin. We look specifically 
at student perceptions of their academic and social experiences. In addition, we consider the way in which these perceptions relate to their expected reactions to curricular and co-curricular situations likely to happen in their first year of college. In particular, we examine the ways that demographic variables (i.e., ethnicity, gender, first-generation status, and standardized test scores) relate to these beliefs and expectations. A clear understanding of the beliefs students bring with them to college is a critical element of designing successful student support programs and interventions.

\section{Literature Review}

Student success in college depends on more than their socioeconomic status and high school GPA. Rather, various non-cognitive factors (e.g., attitudinal, affective, and personality variables) are valuable indicators for student success. Many believe that non-cognitive factors are even more important than cognitive factors in determining which students end up attaining their educational goals (Heckman, Stixrud, \& Urzua, 2006). Opportunities to develop these non-cognitive factors arise in various contexts, but not typically in direct classroom instruction. Areas such as faculty feedback (Yeager, Johnson, et al., 2014), student engagement/involvement (Sims, Luebsen, \& Guggiari-Peel, 2017), student employment (Curl \& Benner, 2017), living situation (Long, 2014), and family involvement (Mailhot \& Feeney, 2017) may impact the growth or development of a student's non-cognitive dispositions.

In addition, non-cognitive dispositions have been shown to affect student success (Bean \& Eaton, 2000; Farruggia, Han, Watson, Moss, \& Bottoms, 2016). These factors include grit (Duckworth, 2016), growth mindset (Dweck, 2006; Han, Farruggia, \& Moss, 2017), academic self-efficacy (Bandura, 1982; Zajacova, Lynch, \& Espenshade, 2005), persistence (Bandura, 1997), motivation (Morrow \& Ackermann, 2012), and sense of belonging (Kirk \& Lewis, 2015; Tinto, 1993). Taken together, these non-cognitive dispositions create a student mindset that could be called college ready (Conley, 2007). This mindset reflects a complex interplay between academic and social expectations and behaviors. That 
is, in the college context, it is unwise to consider the academic separate from the social domain (and vice versa).

The larger conclusion from student success research is that helping students develop a college-ready mindset - that is, one productive for college success - will increase student learning, retention, and graduation. However, research has yet to explain the mindset students bring with them to college. For this reason, this study considers three aspects of the so-called college-ready mindset - mindset, cognition, and goal orientation - for incoming college students. Further, because of the variety of experiences students face in their first year of college, we consider aspects of the college-ready mindset that deal with both academic and co-curricular aspects of their experience. When we understand incoming students' mindsets more clearly, intervention and support programs are more effective.

\section{Mindset}

The first component of the college-ready mindset is students' growth mindset. Broadly speaking, growth and fixed mindset refer to people's beliefs about their abilities and talents. Those who have a fixed mindset "believe that their talents and abilities are simply fixed. They have a certain amount and that's that" (Dweck, 2009, p. 4). On the other hand, those with a growth mindset "think of talents and abilities as things they can develop - as potentials that come to fruition through effort, practice, and instruction (Dweck, 2009, p. 4). Though these mindsets have typically come to refer to beliefs about intelligence, they are not limited to the cognitive sphere. Dweck herself has applied mindset to athletics and coaching. In this study, we are considering mindset broadly to include students' beliefs about their academic abilities and social skills, particularly because success in the first year requires resilience and adaptation to a variety of cognitive and non-cognitive challenges.

Those who have a fixed mindset understand their talent and abilities to be innate characteristics which are primarily set at birth and unchangeable (Dweck, 2006; Elliott \& Dweck, 1988). In this view, failure marks the firm limit of talent or ability. Not surprisingly, students with 
such a mindset have low motivation (Dweck, 2006) and display low effort (Hulleman \& Harackiewicz, 2009). On the other hand, people who display a growth mindset believe that their talent and abilities are not static, but change with effort (Dweck, 1999). Students with growth mindset welcome and seek challenges because they do not understand challenge to lead invariably to failure (Hong, Chiu, Dweck, Lin, \& Wan, 1999). Rather, overcoming failure fills them with a sense of accomplishment (Nicoll, 2014). As it relates to college success, a stable growth intelligence mindset correlates with increases in motivation (Yeager, Purdie-Vaughns, et al., 2014) and academic and social resilience (Yeager \& Dweck, 2012). These increases also correlate with higher levels of student retention (Broda, et al., 2018; Han, et al., 2017) and increased academic achievement (Cohen \& Sherman, 2014). In addition, several studies demonstrate that growth mindset correlates with lower achievement gaps for underrepresented populations (Cohen, Garcia, Apfel, \& Master, 2006; Nix, Perez-Felkner, \& Thomas, 2015).

Research into the social applications of Dweck's mindset theory are in their infancy, particularly when specifically applied to the transition to college. But early research demonstrates the validity of applying the growth mindset theory in the social sphere. A growth mindset towards shyness has been shown to correlate with reduced social anxiety amongst college students (Valentiner, Mounts, Durik, \& Gier-Lonsway, 2011). Growth mindset is also correlated with increased interpersonal competence, and lower public speaking anxiety (Nordin \& BroeckelmanPost, 2019). Further, growth mindset towards introversion results in a more positive view of social situations and reduced avoidance of social situations (Beer, 2002). Given the novelty of the social situations experienced by students in their first year, and the importance of belonging for success in the first year, social mindset is a particularly important area for analysis.

\section{Cognition}

High-impact practice literature indicates that time and effort spent on educationally significant tasks correlates with increased student 
satisfaction, learning, and retention (Kuh, 2008). Therefore, understanding student expectations about the type of effort they are willing to devote to "educationally significant tasks" is of paramount importance. Need for cognition, which is the disposition describing an individual's willingness and interest to seek out and enjoy effortful cognitive activity (Cacioppo \& Petty, 1982), is another feature of the college-ready mindset.

One aspect of this mindset that impacts student success is a student's willingness to devote cognitive effort towards academic tasks. The kind of thinking students are willing to do, and their approach to that thinking, correlates directly to the depth and permanence of their learning. Recent studies suggest that typical students do not put all that much time into their academic work (e.g., Eagan et al., 2016). In fact, more than $75 \%$ of first-year students report studying fewer than 10 hours per week, while only $5 \%$ report studying more than 20 hours a week. In addition, studies into academic work habits suggest that between $70-95 \%$ of students procrastinate, with around $50 \%$ of students procrastinating habitually (Steel \& Ferrari, 2012; Steel \& Klingsieck, 2016). In terms of the quality of work, research indicates that students use ineffective study practices and default to cramming before exams (Blaisman, Dunlosky, \& Rawson, 2017). It is in the context of these studies that Arum and Roksa (2011) suggest that in addition to poor academic preparation, many students "enter college with attitudes, norms, values and behaviors that are often at odds with academic commitment" (p. 3). Certainly, understanding incoming students' willingness to devote cognitive effort to academic tasks is central to improving their chances for success.

Entrance into college also opens up a new set of social opportunities and realities for each student. These social networks are complicated and require thinking and effort to navigate well. As Conley (2007) puts it, "Success in college is enhanced for students who possess interpersonal and social skills that enable them to interact with a diverse cross-section of academicians and peers" (p. 17). He identified several central social skills, including collaboration and teamwork, understanding the norms of academic culture and the rules of interacting with professors, informal communication, leadership skills, and the ability to interact with people 
from diverse backgrounds. As with other skills, social skills require effort to develop. Therefore, it is also important to understand student willingness to engage in effort and thinking about their social skills.

\section{Goal Orientation}

Finally, students' goal orientation impacts their academic performance (Dweck \& Leggett, 1988; Elliott \& Dweck, 1988). Students oriented towards learning goals seek challenging tasks and those that allow them to develop new abilities. Those students oriented towards performance goals focus more directly on the end result, so they choose tasks that allow them to easily demonstrate their competence, often at the expense of their learning. In part, the impact of goal orientation is evidenced in a student's reaction to perceived failure. For example, according to Bain (2012), the "best” students “didn't worry about making mistakes or looking stupid. They did not see themselves as participating in a competitive game to be the 'smartest kid in the class.' Rather they focused on developing their own talents ... they didn't give up easily" (p. 111). The "best" students that Bain describes are those oriented towards learning goals. In addition, Gale and Parker (2014) suggest that the nonlinear nature of 21st century higher education changes the way that we ought to think about the transition to college, and in their view, transition is defined as "the capability to navigate change" (p. 737). Other research demonstrates that students are more frequently motivated to get a high grade than to learn content in class (Blum, 2016).

Social goal orientations have been a part of the goal orientation research since the 1980s (Maehr \& Nicholls, 1980). Initially, this category of goal orientations referred to social or interpersonal reasons for pursing certain behaviors (Urdan \& Maehr, 1995). However, other research has focused on social goals as distinct ends themselves (Patrick, Anderman, \& Ryan, 2002). Students have social expectations and goals within the college context, and they are oriented toward fulfilling those goals successfully within this context.

In summary, retention and graduation are certainly important goals for institutions of higher learning, and programs supporting students in 
their learning are crucial components of 21st century higher education. However, using principles of effective course design, these programs must start with the students in order to bear maximum effectiveness. This research seeks to explain incoming student beliefs and expectations about their intelligence, work habits, and effort, and in so doing, allows for a more nuanced picture of key aspects of students' mindset when they come to college. By understanding these mindsets better, support services can be better tailored to meet the needs of incoming students.

Given the lack of research about pre-college student expectations, the present study was largely exploratory in nature. Despite this fact, we did have some general expectations about what we would find. We assumed that, as incoming college students, our participants would view their future experiences with an openness to personal and professional growth. In particular, based on past research and the widespread incorporation of mindset interventions in the K-12 curriculum (Yeager et al., 2019), we expected students to report a growth mindset within both the academic and social domains. We also expected that students would be willing to devote cognitive effort with these domains, but with a general preference for avoiding problems or conflicts. Finally, we considered demographic differences in order to get a sense for the potential varieties of incoming college student expectations. In particular, we selected variables that commonly feature in student success discussions-ethnicity, gender, firstgeneration status, and academic preparation.

\section{Method}

\section{Participants}

Participants were 332 incoming freshman (192 women, 130 men, 4 other, 6 missing) enrolled in a summer bridge program at Middle Tennessee State University. This two-week bridge program consists of curricular and co-curricular programming aimed towards improving the retention, progression, and graduation of students, open to any interested student (for more details see Windrow \& Korstange, 2019). Most of the students were African-American ( $n=152,46 \%)$ or Caucasian $(n=149$, 
$45 \%)$, and were 18 years old ( $M=18.07, \mathrm{SD}=0.39)$. Roughly a third of the participants were first-generation students $(n=102,31 \%)$. The sample had an average total ACT score of 21.85 (SD = 4.52). As part of the bridge program, students registered for specific sections of an FYE course, that were either required $(n=53,16 \%)$, elective $(n=228,74 \%)$, or honors ( $\mathrm{n}=32,10 \%)$. For analytic purposes, we collapsed the non-Caucasian participants (African-American, American Indian, Asian-American, Hispanic, Other) into a student of color (SOC) category.

\section{Materials}

The survey included a pair of academic and social measures as well as a series of eight academic and social scenarios that college students might experience. The measures were designed to identify student beliefs in the domains of mindset, cognition, and goal orientation. The purpose of the scenarios was to provide insight about how those beliefs relate to student expectations and behavior in situations likely to occur in the first year of college.

Academic and Social Measures. For the academic realm, we used a popular 8-item measure (What's my mindset?, n.d.) of student beliefs about intelligence, cognition, and goal orientation in the academic domain (Burgoyne \& Macnamara, 2020; see Table 2 for all items). The measure includes items based on Dweck's mindset work (Blackwell, Trzesniewski, \& Dweck, 2007; Dweck \& Sorich, 1999) and other research on learning goals (Midgley et al., 1998). This measure is not unidimensional (Burgoyne \& Macnamara, 2020) and researchers have identified issues with its internal consistency (Barnett, Avila, \& Aklog, 2017). Therefore, we analyzed these data at the individual item level rather than by using a total intelligence mindset score.

Participants rated the items using a 6-point Likert scale ( $0=$ strongly disagree, 5 = strongly agree).

- For the mindset items, higher scores indicated a greater growth orientation;

- for the cognition items, higher scores indicated a greater enjoyment of thinking; 
- for the goal orientation items, higher scores indicated a greater desire for school work with minimal trouble and mistakes and more of a performance than learning orientation.

We also adapted this measure to reflect the same features within the social domain. The adapted measure included student beliefs about social skills, cognition, and goal orientations within this domain (see Table 3 for all items). We also analyzed these data at the individual item level.

- For the mindset items, higher scores indicated a greater growth orientation toward social skills;

- for the cognition items, higher scores indicated a greater enjoyment of thinking of the social domain;

- for the goal orientation items, higher scores indicated a greater desire for social activities with minimal trouble and mistakes and more of a performance than learning orientation.

Academic and Social Situation Scenarios. We designed eight scenarios (four academic and four social, two positive and two negative within each domain) to get information about students' expectations about potential upcoming college experiences. We were interested in how student beliefs are reflected in their expectations about events that are likely to occur upon entering college. Specifically, we wanted to tap into students' cognitive, emotional, and motivational reactions to events likely to occur in their first year of college.

The authors generated the scenarios based on ideas and feedback from a convenience sample of high school students. We worded the information to suggest that different authentic responses could be made to each situation. These scenarios were designed to determine how students would approach (or avoid) those different situations, depending on their domain-specific beliefs. The full wording of the scenarios and their types appears in Table 1. 


\section{Academic/Positive}

[Good Project] Imagine that you have just found out that you will have to do a project for one of your college classes. The professor lets you pick from a list of subjects. You go the extra mile to accomplish everything that is required by the assignment and then some. Soon after presenting your project you get your grade back and you did better than you had anticipated and your professor encouraged you to consider presenting your project at a school function that was coming up.

[Good Professor] Imagine that you are halfway through the semester when you have a setback due to personal reasons (such as financial, health, or family issues). You feel that it is starting to take a toll on your grades in one course in particular. You are now at a point in the semester where you are not sure if you will pass this course. Your professor reassures you that you can do well in their course and suggests that you come by their office to see how they can possibly help prevent you from falling behind.

\section{Academic/Negative}

[Paper Grade] Imagine that you worked on a paper for one of your classes-you put a lot of work into this paper and you are anxious to see what your professor thought. When you get your grade back you see that it is much lower than you expected it to be. Your professor also gave a lot of feedback to justify why they gave you that grade.

[Final Grade] Imagine that it is the beginning of the semester and you are in a college class that you believe isn't your strongest subject. However, it is a required course for something you might major in. You still work extremely hard, but you keep telling yourself that you are not going to get upset if you do badly in this course because you know it is not your strongest subject. At the end of the semester your final grade is as bad as you thought it would be.

\section{Social/Positive}

[Org Fair] Imagine that you are on campus and you are walking to class when you suddenly notice a fair with members of many campus 
organizations. You decide to walk through because you haven't had time to even consider extracurricular activities. As you are walking through someone approaches you about an organization that they are involved in. They explain what their organization does and how they reach out to the community. After speaking with them for a few minutes, the member tells you they think you would be a good fit for their organization and encourages you to apply.

[Student Invite] Imagine that you decide to go to a social function on campus one evening. You initially didn't want to go because you had homework, but your friends talked you into going. Soon after arriving, you meet another student with whom you share a lot in common. Before you leave, they invite you to another campus event at the end of the week.

\section{Social/Negative}

[Club Reject] Imagine that you have just found a club on campus that you would like to join. You see that they are accepting new members and find out the requirements for applying. You think this would be a good opportunity for you to get involved and it would look good on your academic resume. You put in your application, but you soon find out that you didn't get picked to be one of the new members but are told to follow the group on social media and to reapply the next semester.

[Roommate] Imagine that you have moved into the place where you will be living for your first year in college. After your first few weeks, one of your roommates starts to come home late at night, bringing over people at all times of the evening, and genuinely making it hard for you to get anything done and get a good night's sleep. It is starting to really bother you and you are considering confronting your roommate about the situation.

For each of the scenarios, students used a 5-point Likert scale (1 = strongly disagree, 5 = strongly agree) to rate six "approach" and "avoidance" statements related to that situation. The approach items included that they would be happy if the situation happened to them, they would be motivated to do something about the situation, and they would look at the situation as an opportunity. The avoidance items included that they would be upset if the situation happened to them, they would avoid doing anything about the situation, and they would look at the situation as a threat. 


\section{Procedure}

Participants completed the survey on the second day of the bridge program, during their FYE course. They first received and signed an informed consent form. We described the survey as part of a research project in which "we are interested in understanding how students perceive different academic and social situations" and "several hypothetical situations that you might encounter during your academic career." We counterbalanced the order of the mindset and scenario measures. We also counterbalanced the order in which the participants rated the academic and social scenarios. The entire survey took approximately 15 minutes to complete.

\section{Results}

\section{Academic and Social Domains}

We first examined the incoming students' mean scores on the academic and social measures. As Table 2 shows, academic responses were significantly different from the scale mid-point (2.50) for all eight items. In particular, participants tended to rate the mindset items toward a growth perspective, the cognition items toward higher enjoyment of thinking, and the goal orientation items toward a preference for minimizing trouble and mistakes.

Table 2. Descriptive Statistics on the Academic Measures

\begin{tabular}{|c|c|c|c|c|}
\hline Category \& Item & M & SD & $\mathbf{t}$ & $\mathbf{p}$ \\
\hline \multicolumn{5}{|l|}{ Mindset } \\
\hline No matter how much intelligence you & 3.94 & 1.01 & 25.77 & 0.0 \\
\hline have, you can always change it a good deal. & & & & \\
\hline $\begin{array}{l}\text { You can learn new things, but you cannot } \\
\text { really change your basic level of intelligence.* }\end{array}$ & 1.91 & 1.3 & 8.24 & 0.0 \\
\hline
\end{tabular}

\section{Cognition}

\begin{tabular}{llll}
\hline I like my work best when it makes me think hard.3.05 & 1.11 & 9.1 & 0.0
\end{tabular}

I like work that I'll learn from even if I make $\begin{array}{rrrr}3.79 & 1.09 & 21.53 & 0.0\end{array}$ lots of mistakes. 
When something is hard, it just makes me

want to work more on it not less.

To tell the truth, when I work hard, it makes

1.891 .59

$6.98 \quad 0.0$

me feel as though I'm not very smart.*

\section{Goal Orientation}

I like my work best when I can do it really well without too much trouble.

I like my work best when I can do it perfectly $\begin{array}{lllll}3.66 & 1.3 & 16.28 & 0.0\end{array}$ without any mistakes.

Note. $N=332$; analyses were based on the scale midpoint (2.50); ${ }^{*}=$ reverse scored .

The pattern of results for the social domain showed both similarities and differences from those in the academic domain (see Table 3). Specifically, participants tended to rate the social mindset items similarly to the academic mindset items, that is towards growth. For their ratings of the cognition items, participants reported being willing to work hard and learn in social situations, but they did not necessarily enjoy difficult social interactions. The goal orientation items showed a preference for minimizing trouble and mistakes in the social domain.

Table 3. Descriptive Statistics on the Social Measures

\begin{tabular}{lllll}
\hline Category \& Item & M & SD & t & p \\
\hline Mindset & & & & \\
\hline $\begin{array}{l}\text { No matter how many social skills you have, } \\
\text { you can always change them a good deal. }\end{array}$ & 3.98 & 1.01 & 26.45 & 0.0 \\
$\begin{array}{l}\text { You can learn new things, but you cannot } \\
\text { really change your basic social skills.* }\end{array}$ & 1.95 & 1.42 & 7 & 0.0
\end{tabular}

\section{Cognition}

\begin{tabular}{lllll}
\hline I like social interactions best when I have to & 1.74 & 1.34 & 10.26 & 0.0
\end{tabular} work hard at them. 
I like social interactions best that I'll learn

from even if I make lots of mistakes.

$\begin{array}{lllll}\text { When a social interaction is hard, it just makes } & 2.79 & 1.38 & 3.85 & 0.0\end{array}$ me want to work more on it, not less.

$\begin{array}{llll}\text { To tell the truth, when I work hard on my social 2.54 } & 1.7 & 0.44 & 0.07\end{array}$ interactions, it makes me feel as though my social skills aren't very good.*

\section{Goal Orientation}

I like social interactions best when I can $\begin{array}{llll}4.17 & 0.89 & 34.11 & 0.0\end{array}$ participate in them really well without too much trouble.

$\begin{array}{lllll}\text { I like my social interactions to go perfectly } & 3.64 & 1.2 & 17.26 & 0.0\end{array}$ without any mistakes.

Note. $N=332$; analyses were based on the scale midpoint (2.50); * reversescored.

\section{Ethnicity and Gender Comparisons}

Because of the large number of comparisons, we used a more conservative alpha level $(\mathrm{p}=.01)$ in determining significant differences. With respect to ethnicity, we compared the Caucasian and student-of-color (SOC) participants on all of the major measures. There were five significant differences, the majority of which fell in the social sphere. As Table 4 indicates, compared to the Caucasian students, the SOC participants were more likely to report that hard work and mistakes in social interactions do not negatively affect their beliefs about their social or academic skills. The goal orientation items showed the SOC participants indicated more of an orientation toward learning and progress in their social interactions than Caucasian participants. 
Table 4. Ethnic Differences on the Social and Academic Measures

\begin{tabular}{|c|c|c|c|c|c|c|}
\hline \multirow[b]{2}{*}{ Category \& Item } & \multicolumn{2}{|c|}{$\begin{array}{l}\text { Caucasian } \\
(n=149)\end{array}$} & \multicolumn{2}{|c|}{$\begin{array}{l}\text { SOC } \\
(n=175)\end{array}$} & \multirow[b]{2}{*}{$\mathbf{t}$} & \multirow[b]{2}{*}{$\mathbf{p}$} \\
\hline & $\mathbf{M}$ & SD & $\mathbf{M}$ & SD & & \\
\hline \multicolumn{7}{|l|}{ Academic Cognition } \\
\hline $\begin{array}{l}\text { To tell the truth, when I } \\
\text { work hard, it makes me fe } \\
\text { as though I'm not very sm }\end{array}$ & $\begin{array}{l}\text { el } \\
\text { art.* }\end{array}$ & 1.6 & 1.67 & 1.55 & 2.65 & .008 \\
\hline
\end{tabular}

\section{Social Cognition}

To tell the truth, when I $\quad 3.01 \quad 1.6$

$\begin{array}{llll}2.09 & 1.66 & 5.06 & .000\end{array}$

work hard on my social interactions,

it makes me feel like my social

skills aren't very good.*

I like the kind of social $\quad 2.511 .4$

$\begin{array}{llll}3.13 & 1.31 & 4.06 & .000\end{array}$

interactions best that I'll learn

from even if I make a lot of mistakes.

\section{Social Goal Orientation}

\begin{tabular}{lllllll}
\hline I like social interactions best & 4.31 & 0.76 & 4.07 & 0.95 & 2.5 & .013
\end{tabular}

when I can participate in them really

well without too much trouble.

$\begin{array}{lllllll}\text { I like my social interactions to } & 3.85 & 1.1 & 3.48 & 1.26 & 2.78 & .006\end{array}$ go perfectly without any mistakes.

With respect to gender, there were five significant differences on the academic and social items. As Table 5 shows, men reported greater fixedness than women, primarily within the academic domain, as well as more of a performance than a learning orientation in both the academic and social domains. 
Table 5. Gender Differences on the Academic and Social Measures

\begin{tabular}{|c|c|c|c|c|c|c|}
\hline \multirow[b]{2}{*}{ Category \& Item } & \multicolumn{2}{|c|}{$\begin{array}{l}\text { Men } \\
(n=129)\end{array}$} & \multicolumn{2}{|c|}{$\begin{array}{l}\text { Women } \\
(n=192)\end{array}$} & \multirow[b]{2}{*}{$\mathbf{t}$} & \multirow[b]{2}{*}{ p } \\
\hline & $\mathbf{M}$ & SD & $\mathbf{M}$ & SD & & \\
\hline \multicolumn{7}{|l|}{ Academic Mindset } \\
\hline $\begin{array}{l}\text { You can learn new things, but } \\
\text { you cannot really change your } \\
\text { basic level of intelligence.* }\end{array}$ & 2.07 & 1.28 & 1.76 & 1.3 & 2.1 & .036 \\
\hline $\begin{array}{l}\text { I like work that I'll learn from } \\
\text { even if I make lots of mistakes. }\end{array}$ & 3.54 & 1.13 & 3.97 & 1.03 & 3.51 & .001 \\
\hline
\end{tabular}

\section{Academic Cognition}

$\begin{array}{lllllll}\text { When something is hard, it } & 3.05 & 1.24 & 3.42 & 1.2 & 2.68 & .008\end{array}$ just makes me want to work more on it not less.

\section{Academic Goal Orientation}

\begin{tabular}{llllll}
\hline I like my work best when I can do 3.92 & 1.22 & 3.54 & 1.31 & 2.62 & .009
\end{tabular} it perfectly without any mistakes.

\section{Social Goal Orientation}

\begin{tabular}{lllllll}
\hline I like my social interactions to & 3.86 & 1.2 & 3.52 & 1.2 & 2.5 & .013
\end{tabular} go perfectly without any mistakes.

For the scenario ratings, there were also several ethnicity and gender differences. For ethnicity (Table 6), the significant differences arose entirely within the social domain. In particular, SOC participants were more motivated than Caucasian participants to do something about the organization fair invitation. For the student invite scenario, compared to Caucasian participants, SOC participants reported that they would be more upset with the situation, more likely to see it as a threat, and less likely to be motivated to do something about it or see it as an opportunity. Finally, SOC participants were less upset with and slightly happier about the club reject scenario compared to the Caucasian participants. 
Table 6. Ethnic Differences on the Reactions to the Social Scenarios

\begin{tabular}{lllllll}
\hline & \multicolumn{2}{l}{$\begin{array}{l}\text { Caucasian } \\
(\boldsymbol{n}=\mathbf{1 4 9})\end{array}$} & \multicolumn{2}{l}{$\begin{array}{l}\text { SOC } \\
(\boldsymbol{n}=\mathbf{1 7 5})\end{array}$} & & \\
Item & $\mathbf{M}$ & SD & M & SD & t & p \\
\hline Org Fair Motive & 3.75 & 0.94 & 4.00 & 0.79 & 2.56 & 0.01 \\
Student Invite Upset & 1.58 & 0.75 & 1.83 & 0.96 & 2.60 & 0.01 \\
Student Invite Motive & 3.90 & 0.83 & 3.61 & 0.88 & 2.96 & 0.003 \\
Student Invite Opportunity & 4.27 & 0.73 & 3.64 & 1.03 & 6.20 & 0.00 \\
Student Invite Threat & 1.34 & 0.70 & 1.71 & 1.12 & 3.54 & 0.00 \\
Club Reject Upset & 3.90 & 0.83 & 3.62 & 1.01 & 2.73 & 0.007 \\
Club Reject Happy & 1.55 & 0.62 & 1.81 & 0.84 & 3.03 & 0.003
\end{tabular}

Significant gender differences occurred across both domains, though primarily within the social scenarios (see Table 7). In particular, for the academic domain, women saw the paper and final grade scenarios as more of an opportunity compared to men. Women also reported being more motivated to do something about the good project scenario. In the social domain, compared to women, men reported lower levels of happiness, motivation, and opportunity and higher levels of avoidance in the organization fair situation. Women reported lower levels of happiness than did men in the club reject scenario. Finally, women reported that they would be more upset and less happy in the roommate situation than did men. 
Table 7. Gender Differences on the Reactions to the Academic and Social Scenarios

\begin{tabular}{lllllll}
\hline & \multicolumn{7}{l}{$\begin{array}{l}\text { Men } \\
(n=129)\end{array}$} & \multicolumn{2}{l}{$\begin{array}{l}\text { Women } \\
\text { (n= 192) }\end{array}$} & & \\
& M & SD & M & SD & t & p \\
\hline Academic & & & & & & \\
\hline Paper Grade Opportunity & 3.61 & 1.03 & 3.94 & 1 & 2.81 & 0.005 \\
Final Grade Opportunity & 3.09 & 1.18 & 3.48 & 1.2 & 2.81 & 0.005 \\
Good Project Motive & 3.93 & 1.01 & 4.25 & 0.89 & 2.65 & 0.009 \\
& & & & & & \\
\hline Social & & & & & & \\
\hline Org Fair Happy & 3.87 & 0.87 & 4.18 & 0.82 & 3.3 & 0.001 \\
Org Fair Motive & 3.71 & 0.86 & 4.02 & 0.85 & 3.23 & 0.001 \\
Org Fair Avoid & 2.16 & 0.92 & 1.82 & 0.9 & 3.29 & 0.001 \\
Org Fair Opportunity & 4.24 & 0.8 & 4.47 & 0.66 & 2.8 & 0.005 \\
Club Reject Happy & 1.82 & 0.77 & 1.6 & 0.73 & 2.65 & 0.009 \\
Roommate Upset & 4.14 & 1.09 & 4.53 & 0.74 & 3.77 & 0.000 \\
Roommate Happy & 1.5 & 0.8 & 1.23 & 0.57 & 3.44 & 0.000
\end{tabular}

\section{The Role of First-Generation College Student Status}

For the next analysis, we compared participants who indicated being or not being a first-generation college student on the 16 academic and social items, using an independent-samples t-test. Results indicated that the two groups did not differ significantly on any of the items. Ratings of the motive, avoid, opportunity, and threat scenario characteristics by firstgeneration status showed only one significant difference. First-generation students $(\mathrm{M}=1.53, \mathrm{SD}=.74)$ were less likely than non-first-generation students $(M=1.85, \mathrm{SD}=1.06)$ to avoid doing anything about the bad final grade scenario, $\mathrm{t}(326)=2.70, \mathrm{p}=.007$.

\section{Relationship of ACT Score to Major Measures}

With respect to the beliefs and work habits, total ACT scores proved to be significantly related to several items (see Table 8). As the table shows, ACT scores were negatively correlated with multiple academic and social items. In general, these relationships reflected more a performance 
than a learning orientation among those with higher ACT scores. There were no significant differences on the academic or social mindset items.

Table 8. Correlations between ACT Scores and the Academic and Social Measures

Total ACT

r p

\section{Academic Cognition}

I like work that I'll learn from even.$- .111 \quad 0.048$ $-.129 \quad 0.02$ if I make lots of mistakes.

When something is hard, it just $\quad-.146 \quad 0.009$ $-.112 \quad 0.047$
Benchmarks $\mathbf{r} \quad \mathbf{p}$ p

makes me want to work more on it, not less.

\section{Academic Goal Orientation}

\begin{tabular}{llll}
\hline I like my work best when I can do it -.185 & 0.001 & -.121 & 0.03
\end{tabular} really well without too much trouble.

\section{Social Cognition}

I like social interactions best $-.260 \quad 0.00$ $-.257 \quad 0.00$

when I have to work hard at them.

I like social interactions best that I'll -.319 0.00

learn from even if I make lots of mistakes.

When a social interaction is hard, $\quad-.228 \quad 0.00$ $-.198 \quad 0.00$

it just makes me want to work more on it, not less.

$\begin{array}{lllll}\text { To tell the truth, when I work hard } & -.228 & 0.00 & -.198 & 0.00\end{array}$ on my social interactions, it makes me feel as though my social skills aren't very good.*

\section{Social Goal Orientation}

I like my social interactions $.198 \quad 0.00$ $.218 \quad 0.00$

to go perfectly without any mistakes.

Note. $N=317 .{ }^{*}=$ reversed-scored; items were rated using a 6-point scale (0 = strongly disagree, 5 = strongly agree). 
Finally, we examined how the number of ACT benchmarks attained related to the various measures. To create this variable, we used the ACT benchmark cutoff definition for each subscale, which the ACT suggests are the minimal scores associated with success in first-year college courses (Allen \& Radunzel, 2017). Students who did not meet the benchmark received a score of 0 , with students meeting or exceeding the benchmark receiving a 1 . Thus, the range of scores for this ACT Benchmark variable was 0 -4. As Table 8 indicates, there were several significant correlations between the number of benchmarks met and the cognition and goal orientation measures. These correlations paralleled the results for the total ACT score.

For the scenario ratings, total ACT score was positively related to four measures: org fair avoid $(\mathrm{r}(315)=.143, \mathrm{p}=.011)$, student invite motive $(r(315)=.190, p=.001)$, student invite opportunity $(r(315)=.275, p=$ $.000)$, and roommate avoid $(\mathrm{r}(315)=.163, \mathrm{p}=.004)$. Total ACT score was negatively related to student invite threat $(\mathrm{r}(315)=-.115, \mathrm{p}=.042)$. With the benchmark data, participants' ratings of the scenarios showed five significant positive correlations, all of which occurred with responses to social rather than academic situations. In particular, as the number of benchmarks met increased, participants agreed more with the org fair avoid $(\mathrm{r}(315)=.193, \mathrm{p}=.001)$, student invite motive $(\mathrm{r}(315)=.171, \mathrm{p}$ $=.002)$, student invite opportunity $(\mathrm{r}(315)=.245, \mathrm{p}=.000)$, club reject avoid $(\mathrm{r}(315)=.116, \mathrm{p}=.040)$, and roommate avoid $(\mathrm{r}(315)=.154, \mathrm{p}=$ $.006)$.

\section{Discussion}

The purpose of this study was to explore incoming college students' beliefs about their mindset, perceived need for cognition, and goal orientation before they began their post-secondary academic career in full. Our critical pre-supposition was that a detailed understanding of incoming student beliefs is an essential foundation for both effective teaching and transition programming. This section highlights the major results and implications of the study. 


\section{Mindset}

Our results suggest a few significant and interesting elements of students' mindsets. First, in the aggregate, participants in this study tended to rate the mindset items towards a growth perspective in both the academic and social domains. This finding casts some doubt on the larger trend in student success programming to see growth mindset as a silver bullet for student success and confirms the increasing call in the research literature to carefully assess the outcomes of educational interventions (Robbins, Oh, Le, \& Button, 2009; Sriram, 2014). Put simply, if students come to college with growth-oriented beliefs, then interventions aimed at helping students develop or establish their growth mindset will be limited in their effectiveness.

Further, participants of color were more likely to report that hard work and mistakes in social interactions do not negatively affect their beliefs about their social skills. This result suggests that SOC participants report a more growth approach to developing their social skills compared to Caucasian students. Surprisingly, within specific social scenarios, SOC participants reported higher levels of avoidance and lower levels of approach behaviors compared to Caucasian students. The result suggests more of a fixed than a growth approach to social interactions, despite the beliefs that SOC participants endorsed. This result might be mitigated by the fact that at the institution where the data were collected, enrollment was 65\% Caucasian, making this a predominantly white institution (PWI). Studies indicate that students of color report feeling isolated and out of place at PWIs (Watson et al., 2002), and report feeling unhappy with social engagement and possible experiences of racism and hostility (Palmer \& Young, 2010). This research is consistent with these studies, particularly in the responses to the student invite and club reject scenarios, where students of color saw the situations as more of a threat than did Caucasian participants.

Men reported a greater fixed academic mindset than did women. Other research shows that women approach their education more seriously than do men (e.g., Voyer \& Voyer, 2014). Our results are consistent with this finding. Further evidence arose in the scenario results 
where women reported seeing several academic situations as more of an opportunity and being more motivated in these situations compared to men. These results suggest that the women in our sample are coming into college more primed for success, at least with respect to being proactive about their education, compared to men. Stated differently, female participants reported higher growth intelligence mindset than male participants, and anticipated operationalizing that growth mindset by being more motivated and finding more opportunity in academic situations.

\section{Cognition}

Participants reported a need for academic cognition, indicating that students are coming to college knowing that learning is going to take cognitive work. The stability of the student perception of need for cognition is not clear from this study, nor are the specific strategies which students use to devote effort and energy to their academic tasks, though previous research indicates that students use ineffective academic strategies (e.g., Blaisman et al., 2017). Successful transition programming can capitalize on students' perceived need for cognition and direct that need towards the development of effective and efficient study strategies. Participants also reported a willingness to work hard and learn in social situations, though they did not expect to enjoy difficult social interactions. Learning in co-curricular contexts continues to be a critical aspect of the college experience (Huang \& Chang, 2004; Kuh, 1995) and this result indicates that students recognize the value of co-curricular education and are willing to devote cognitive effort to their social growth.

In addition, students with high ACT scores or benchmark attainment reported a lower need for cognition. This result likely reflects trends in secondary education where students avoid the risk of challenging learning situations (Dweck \& Master, 2009) and overlaps with a performance goal orientation as discussed below. One implication is that high ACT scorers, while typically falling outside of the profile of high-risk students, appear less inclined to recognize the need for the effort that deep and transferable learning requires. This result implies that 
high ACT scorers might be better characterized as "strategic" than "deep" learners (Bain, 2012). That is, they may be more interested in maintaining high academic performance through purposeful navigation of a flawed educational system rather than by mastering disciplinary content (Blum, 2016). Tailored interventions for high performers might, therefore, be worth pursuing.

\section{Goal Orientation}

By and large, participant responses indicate a preference for performance rather than learning orientation, in both the academic and social spheres. Other research demonstrates a correlation between performance goal orientation, specifically that which is aimed to hide inability, and maladaptive patterns of learning and increased dropout (Peggy, Sullivan, \& Guerra, 2007). Other research suggests that learning goal orientation is not easily changed, indicating the need for the development of intentional programming to help students develop a more productive goal orientation (DeShon \& Gillespie, 2005).

The student preference for a performance goal orientation is potentially related to the preparedness gaps that a pool of hiring managers and business executives have identified amongst recent college graduates (Hart Research Associates, 2018). Specifically, employers point to gaps in students' critical thinking and analytical reasoning, application of knowledge and skills to the real world, oral communication, and selfmotivation. Much research (e.g., Hoyert \& O’Dell, 2009) supports the idea that a learning goal orientation is superior to a performance orientation when it comes to the development of these essential workplace skills.

Two areas of demographic difference are worth highlighting. Students of color showed more of a learning goal orientation in the social sphere. This result correlates with other findings suggesting that Black and biracial students are more engaged than White students at PWIs (Harris \& BrckaLorenz, 2017). In addition, students with higher ACT scores reported greater performance goal orientation in both the academic and social domains. Within the academic domain, this result is consistent with our earlier interpretation of the use of a "strategic" learning approach 
among these students. Furthermore, these high-performing students seemed less interested in taking social risks, as reflected by the avoidance data from the social scenarios. There is some evidence that high levels of standardized-test performance are associated with social awkwardness and lower perceptions of social skills (Gross, 2002; Jackson \& Peterson, 2003).

\section{First-Generation Status}

Across the study, first-generation students did not differ significantly from other students in their academic and social beliefs. These are interesting results because they suggest that being unfamiliar with college norms and practices are unrelated to incoming students' beliefs or their anticipated reactions to situations likely to happen in the first year. However, first-generation students are at least four times more likely to leave college without a degree than non-first-generation students (Engle \& Tinto, 2008). This points to a larger question - given that students' beliefs about their intelligence, perceived need for cognition, and goal orientation do not significantly differ based on generational status, why is there such a prominent retention deficit amongst first-generation students? More research is certainly needed, but at this point, it seems likely that the answer lies outside of the areas of academic preparation or student mindset.

\section{Limitations and Implications for Future Research}

We note three limitations with respect to the present study. First, the popular 8-item measure (What's my mindset?, n.d.) of student beliefs about intelligence, cognition, and goal orientation in the academic domain has been shown to be multidimensional and not solely an indicator of intelligence mindset (Burgoyne \& Macnamara, 2020). Our use of this measure provided insight into several important features of students' beliefs that shape their transition into college, but the development of more detailed measures for mindset, cognition, and goal orientation in both the social and academic domains would be a worthy goal for future research.

Second, our sample consisted of attendees at a summer bridge/ early arrival program. It is possible that the nature of this sample 
prejudiced the results towards indicating growth mindset positions, an increased need for cognition, and certain goal orientations. In particular, these students were willing to arrive on campus two weeks before the semester began for the expressed purpose of being well prepared for college when the semester began. Future research should expand the sample and include a broader segment of incoming students, as well as compare the beliefs and expectations of students who do and do not participate in bridge/early arrival programs.

Finally, our results might be subject to the Dunning Kruger effect, which describes the overestimation of one's abilities in intellectual and social domains (Kruger \& Dunning, 1999). Surveying students about their beliefs and expectations before their college courses began is an important starting point, but questions about the stability of these student beliefs remain, particularly in light of the personal challenges inherent to the transition to college. Further research should examine the extent to which students maintain or change their incoming perceptions and beliefs throughout their college career and identify the varied opportunities and threats that correlate with belief change.

In conclusion, our results highlight the importance of understanding students' mindset, cognition, and goal orientation in both the academic and social domains. Student beliefs in each of these domains shape critical elements of their first-year experience, provide key context for their learning, and directly correlate with the value students find in their educational pursuits. As we have noted, understanding student beliefs as they come to college therefore provides a vital context for the successful design of first-year courses and student support programming.

\section{References}

Allen, J., \& Radunzel, J. (2017, October). What are the ACT college readiness benchmarks? ACT Research \& Policy Issue Brief. Retrieved from: https://www.act.org/content/dam/act/unsecured/documents/pdfs/ R1670-college-readiness-benchmarks-2017-11.pdf

Arum, R., \& Roksa, J. (2011). Academically Adrift. Chicago: The University of Chicago Press. 
Bain, K. (2012). What the best college students do. Cambridge, MA: Belknap Press of Harvard University Press.

Bandura, A. (1982). Self-efficacy mechanism in human agency. American Psychologist, 37(2), 122-147. http://dx.doi.org/10.1037/0003066X.37.2.122

Bandura, A. (1997). Self-efficacy: The exercise of control. Macmillan. Barnett, E., Avila, O., \& Aklog, F. (2017, March). An analysis of the development of positive academic mindsets in diverse IBO schools. National Center for Restructuring Education, Schools, and Teaching. New York, NY: Teachers College, Columbia University.

Bean, J. P., \& Eaton, S. B. (2000). A psychological model of college student retention. In J. M. Braxton (Ed.), Reworking the departure puzzle (pp. 48-61). Nashville: Vanderbilt University Press.

Beer, J. S. (2002). Implicit self-theories of shyness. Journal of Personality and Social Psychology, 83(4), 1009-1024. https://doi. org/10.1037/0022-3514.83.4.1009

Blackwell, L., Trzesniewski, K., \& Dweck, C. (2007). Implicit theories of intelligence predict achievement across an adolescent transition: A longitudinal study and an intervention. Child Development, 78, 246263. http://dx.doi.org/10.1111/j.1467-8624.2007.00995.x

Blaisman, R., Dunlosky, J., \& Rawson, K. (2017). The what, how much, and when of study strategies: comparing intended versus actual study behaviour. Memory, 25(6), 784-792. https://doi:10.1080/09658211.2 016.1221974

Blum, S. D. (2016). I love learning, I hate school: An anthropology of college. Ithaca, NY: Cornell University Press.

Broda, M., Yun, J., Schneider, B., Yeager, D. S., Walton, G. M., \& Diemer, M. (2018). Reducing inequality in academic success for incoming college students: A randomized trial of growth mindset and belonging interventions. Journal of Research on Educational Effectiveness, 11(3), 317-338. https://doi.org/10.1080/19345747.2018.1429037 Burgoyne, A. P., \& Macnamara, B. N. (2020, February 2). The reliability and validity of the mindset assessment profile tool. https://doi. org/10.31234/osf.io/hx53u 
Cacioppo, J. T., \& Petty, R. E. (1982). The need for cognition. Journal of Personality and Social Psychology, 42(1), 116-131. https://doi. org/10.1037/0022-3514.42.1.116

Castleman, B. L., \& Meyer, K. (2018). Nudges, Norms, and Navigation: Behavioral insights to improve student success. In R. S. Feldman (Ed.), The First Year of College: Research, Theory, and Practice on Improving the Student Experience and Increasing Retention (pp. 249-276). Cambridge: Cambridge University Press.

Cohen, G. L., Garcia, J., Apfel, N., \& Master, A. (2006). Reducing the racial achievement gap: a social-psychological intervention. Science, 313(5791): 1307-1310. https://doi.org/10.1126/science.1128317

Cohen, G. L., \& Sherman, D. K. (2014). The psychology of change: Selfaffirmation and social psychological intervention. Annual Review of Psychology, 65, 333-371. https://doi.org/10.1146/annurevpsych-010213-115137

Conley, D. (2007) Redefining college readiness. Educational Policy Improvement Center.

Curl, A. L., \& Benner, K. (2017) The influence of employment on college students' academic experiences. Journal on Excellence in College Teaching, 28(3), 183-200.

DeShon, R. P., \& Gillespie, J. Z. (2005). A motivated action theory account of goal orientation. Journal of Applied Psychology, 90(6), 1096-1127. https://doi.org/10.1037/0021-9010.90.6.1096

Duckworth, A. (2016). Grit: The power of passion and perseverance. Simon and Schuster.

Dweck, C. S. (1999). Essays in social psychology. Self-theories: Their role in motivation, personality, and development. New York, NY, US: Psychology Press.

Dweck, C. S. (2006). Mindset: The new psychology of success. Random House Incorporated.

Dweck, C. S. (2009). Mindsets: developing talent through a growth mindset. Olympic Coach, 21(1), 4-7.

Dweck, C. S., \& Leggett, E. L. (1988). A social-cognitive approach to motivation and personality. Psychological Review, 95, 256-273. 
Dweck, C. S., \& Master, A. (2009). Self-Theories and motivation: Students' beliefs about intelligence. In K. R. Wentzel \& D. B. Miele (Eds.), Handbook of motivation at school (pp. 137-154). Routledge.

Dweck, C. S., \& Sorich, L. A. (1999). Mastery-oriented thinking. In C. R. Snyder (Ed.), Coping: The psychology of what works (pp. 232-251). New York: Oxford University Press.

Eagan, K., Stolzenberg, E. B., Zimmerman, H. B., Aragon, M. C., Sayson, H. W., \& Rios-Aguilar, C. (2016). The American freshman: National norms fall 2016. Retrieved from https://www.heri.ucla.edu/monographs/ TheAmericanFreshman2016.pdf

Elliott, E. S., \& Dweck, C. S. (1988). Goals: An approach to motivation and achievement. Journal of Personality and Social Psychology, 54(1), 5-12. http://dx.doi.org/10.1037/0022-3514.54.1.5

Engle, J., \& Tinto, V. (2008). Moving beyond access: College success for low-income, first-generation students. Pell Institute for the Study of Opportunity in Higher Education. Retrieved from http://www.eric. ed.gov/PDFS/ED504448.pdf

Farruggia, S. P., Han, C.-W., Watson, L., Moss, T. P., \& Bottoms, B. L. (2016). Noncognitive factors and college student success. Journal of College Student Retention: Research, Theory \& Practice, 0(0), 1-20. https:// doi:10.1177/1521025116666539

Gale, T., \& Parker, S. (2014). Navigating change: A typology of student transition in higher education. Studies in Higher Education, 39, 734753. https://doi.org/10.1080/03075079.2012.721351

Gross, M. U. M. (2002). Social and emotional issues for exceptionally intellectually gifted children. In M. Neihard, S. M. Reis, N. M. Robinson, \& S. M. Moon (Eds.), Social and emotional development of gifted children: What do we know? (pp.19-30). Waco, TX: Prufrock Press.

Han, C.-w., Farruggia, S. P., \& Moss, T. P. (2017). Effects of Academic Mindsets on College Students' Achievement and Retention. Journal of College Student Development, 58(8), 1119-1134. https://doi. org/10.1353/csd.2017.0089 
Harris, J. C., \& BrckaLorenz, A. (2017). Black, White, and Biracial students' engagement at differing institutional types. Journal of College Student Development, 58(5), 783-789. https://doi.org/10.1353/ csd.2017.0061

Hart Research Associates. (2018). Fulfilling the American Dream: Liberal Education and the future of work. Washington, DC: Association of American Colleges and Universities.

Heckman, J. J., Stixrud, J., \& Urzua, S. (2006). The effects of cognitive and noncognitive abilities on labor market outcomes and social behavior. Journal of Labor economics, 24(3), 411-482. https://doi. org/10.1086/504455

Hong, Y.-y., Chiu, C.-y., Dweck, C. S., Lin, D. M.-S., \& Wan, W. (1999). Implicit theories, attributions, and coping: A meaning system approach. Journal of Personality and Social Psychology, 77(3), 588-599. https:// doi.org/10.1037/0022-3514.77.3.588

Hoyert, M. S., \& D. O’Dell, C. (2009). Goal Orientation and Academic Failure in Traditional and Nontraditional Aged College Students. College Student Journal, 43(4), 1052-1061.

Huang, Y., \& Chang, S. (2004). Academic and cocurricular involvement: Their relationship and the best combinations for student growth. Journal of College Student Development, 45(4), 391-406. https://doi. org/10.1353/csd.2004.0049

Hulleman, C. S., \& Harackiewicz, J. M. (2009). Promoting interest and performance in high school science classes. Science, 326, 1410-1412. https://doi.org/10.1126/science.1177067

Jackson, P. S., \& Peterson, J. (2003). Depressive disorder in highly gifted adolescents. The Journal of Secondary Gifted Education, 16(3), 175186.

Kirk, C. M., \& Lewis, R. K. (2015). Sense of community on an urban, commuter campus. International Journal of Adolescence and Youth, 20(1), 48-60.

Kruger, J., \& Dunning, D. (1999). Unskilled and unaware of it: How difficulties in recognizing one's own incompetence lead to inflated self-assessments. Journal of Personality and Social Psychology, 77(6), 
1121-1134. https://doi.org/10.1037/0022-3514.77.6.1121

Kuh, G. D. (1995). The other curriculum: Out-of-class experiences associated with student learning and personal development. The Journal of Higher Education, 66(2), 123-155. https://doi.org/10.1080 /00221546.1995.11774770

Kuh, G. D. (2008). High-impact educational practices: What they are, who has access to them, and why they matter. Report from the Association of American Colleges and Universities.

Long, L. D. (2014). Does It Matter Where College Students Live?

Differences in Satisfaction and Outcomes as a Function of Students' Living Arrangement and Gender. Journal of College and University Student Housing, 40(2), 66-85.

Maehr, M. L., \& Nicholls, J. G. (1980). Culture and achievement motivation: A second look. In N. Warren (Ed.), Studies on cross-cultural psychology, vol. 2 (pp. 221-267). New York: Academic.

Mailhot, B. E., \& Feeney, S. L. (2017). Perceived parental involvement and academic achievement of college students: The mediating role of academic self-concept. North American Journal of Psychology, 19(3), 685-708.

Midgley, C., Kaplan, A., Middleton, M., Maehr, M. L., Urdan, T., Anderman, L. H., Anderman, E., \& Roeser, R. (1998). The development and validation of scales assessing students' achievement goal orientations. Contemporary Educational Psychology, 23, 113 - 131.

Morrow, J., \& Ackermann, M. (2012). Intention to persist and retention of first-year students: The importance of motivation and sense of belonging. College Student Journal, 46, 483-491.

National Center for Education Statistics. (2018). The Condition of Education 2018 (NCES 2018-144), Undergraduate Retention and Graduation Rates.

Nicoll, W. G. (2014). Developing transformative schools: A resiliencefocused paradigm for education. International Journal of Emotional Education, 6(1), 47-65.

Nix, S., Perez-Felkner, L., \& Thomas, K. (2015). Perceived mathematical ability under challenge: a longitudinal perspective on sex segregation 
among STEM degree fields. Frontiers in Psychology, 6, 1-19. https:// doi.org/10.3389/fpsyg.2015.00530

Nordin, K., \& Broeckelman-Post, M. A. (2019) Can I get better? Exploring mindset theory in the introductory communication course.

Communication Education, 68(1), 44-60, https://doi.org/10.1080/03 634523.2018.1538522

Palmer, R. T., \& Young, E. (2010). The uniqueness of an HBCU environment: How a campus-climate promotes student success. In T.L. Strayhorn \& M.C. Terrell (Eds.), The evolving challenges of Black college students: New insights for practice and research (pp. 138-160). Sterling, VA: Stylus.

Patrick, H., Anderman, L. H., \& Ryan, A. M. (2002). Social motivation and the classroom social environment. In C. Midgley (Ed.), Goals, goal structures, and patterns of adaptive learning (pp. 85-108) Mahwah, New Jersey: Erlbaum.

Peggy, P., Sullivan, J. R., \& Guerra, N. S. (2007). A closer look at college students: Self-efficacy and goal orientation. Journal of Advanced Academics, 18(3), 454-476.

Robbins, S. B., Oh, I.-S., Le, H., \& Button, C. (2009). Intervention effects on college performance and retention as mediated by motivational, emotional, and social control factors: Integrated meta-analytic path analyses. Journal of Applied Psychology, 94(5), 1163-1184. http:// dx.doi.org/10.1037/a0015738

Sims, S., Luebsen, W., \& Guggiari-Peel, C. (2017) Exploring the role of co-curricular student engagement in relation to student retention, attainment and improving inclusivity. The Journal of Educational Innovation, Partnership and Change, 3(1), 93-109.

Sriram, R. (2014). Rethinking intelligence: The role of mindset in promoting success for academically high-risk students. Journal of College Student Retention, 15(4), 515-536. https://doi.org/10.2190/ CS.15.4.C

Steel, P., \& Ferrari, J. (2012). Sex, education and procrastination: An epidemiological study of procrastinators' characteristics from a global sample. European Journal of Personality, 27(1), 51-58. https://doi. org/10.1002/per.1851 
Steel, P., \& Klingsieck, K. B. (2016). Academic Procrastination: Psychological Antecedents Revisited. Australian Psychologist, 1, 36-46. https://doi. org/10.1111/ap.12173

Tinto, V. (1993). Leaving College: Rethinking the Causes and Cures of Student Attrition. Second Edition. University of Chicago Press.

Urdan, T. C., \& Maehr, M. L. (1995). Beyond a two-goal theory of motivation and achievement: A case for social goals. Review of Educational Research, 65, 213-243.

Valentiner, D. P., Mounts, N. S., Durik, A. M., \& Gier-Lonsway, S. (2011). Shyness mindest: Applying mindset theory to the domain of inhibited social behavior. Personality and Individual Differences, 50(8), 11741179.

Voyer, D., \& Voyer, S. D. (2014). Gender differences in scholastic achievement: A meta-analysis. Psychological Bulletin, 140(4), 11741204. http://dx.doi.org/10.1037/a0036620

Watson, L., Terrell, M. C., Wright, D. J., Bonner, F. A., Cuyjet, M.J., Gold, J. A., Donna, E., \& Person, D. R. (2002). How minority students experience college: Implications for planning and policy. Sterling, VA: Stylus.

What's my mindset? (n.d.). Retrieved from http://blog.mindsetworks.com/ what-s-my-mindset?view=quiz

Windrow, V., \& Korstange, R. (2019). Maintaining high-impact bridge programming at scale. Journal of the Scholarship of Teaching and Learning, 19(1), 29-40. https://doi.org/10.14434/josotl.v19i1.26783

Yeager, D. S., \& Dweck, C. S. (2012). Mindsets that promote resilience:

When students believe that personal characteristics can be developed. Educational Psychologist, 47(4), 302-314.

Yeager, D. S., Hanselman, P., Walton, G. M., Murray, J. S., Crosone, R., Muller, C., ... Dweck, C. S. (2019) A national experiment reveals where a growth mindset improves achievement. Nature, 573, 364-369. https://doi.org/10.1038/s41586-019-1466-y

Yeager, D. S., Johnson, R., Spitzer, B. J., Trzesniewski, K. H., Powers, J., \& Dweck, C. S. (2014). The far-reaching effects of believing people can change: Implicit theories of personality shape stress, health, and achievement during adolescence. Journal of Personality and Social 
Psychology, 106(6), 867.

Yeager, D. S., Purdie-Vaughns, V., Garcia, J., Apfel, N., Brzustoski, P., Master, A., \& ... Cohen, G. L. (2014). Breaking the cycle of mistrust: Wise interventions to provide critical feedback across the racial divide. Journal of Experimental Psychology: General, 143(2), 804-824. https://doi:10.1037/a0033906

Zajacova, A., Lynch, S. M., \& Espenshade, T. J. (2005). Self-efficacy, stress, and academic success in college. Research in Higher Education, 46(6), 677-706. https://doi:10.1007/s11162-004-4139-z 